\title{
WHAT IS MORALLY GOOD?
}

\author{
Ramona Nicoleta ARIEŞAN, \\ PhD Student in Philosophy at Babes-Bolyai University, \\ Faculty of Philosophy and History, Cluj-Napoca, \\ ROMANIA, \\ Email: cashmerephotography@gmail.com
}

\begin{abstract}
The purpose of this paper is to show, starting from a personal point of view, what morality means, how it is perceived and how it can affect us. It is an interesting field that holds a lot of meaning. It might just be the reason why we are who we are as people, why we do the things that we do and we believe in them so much. Looking at it from a different angle, for some at least, it might seem as a bad idea as it can stand between them as individuals and reaching their goals without minding their surroundings whether there are people involved or just things. We might never fully understand what is morally good but at least we know that we are doing everything that we can to try and improve our knowledge, to try and improve our own ways of seeing and perceiving life, to try and improve us as persons as human beings. Also, this might be just what we need in order to be able to actually make a difference in this world, to make people believe in something, but most importantly to make them believe in their-selves. Because when one believes in something, when one has personal values, when one can make the difference between good and bad, one can change the world.
\end{abstract}

Keywords: moral; human being; philosophy; life; believe;

\section{HOW TO PERCEIVE SOMETHING THAT IS MORAL}

Defining something that is both good and moral is quite the task. But it is something that this paper is trying to do. Putting into perspective different perceptions and thoughts regarding this subject, giving the opportunity for the people who read it to start a conversation on these bases, an opportunity to address it however they want and to get others involved is something that it's hopped to be achieved with this paper and this matter.

In general, something that is moral is also something that is good. We rarely associate the moral part of life or the moral part of things with a bad or negative aspect. This might be an interesting aspect but is also a general one. Yet, we cannot say that there is no such thing as a bad aspect, a bad reason, a bad person a bad event or bad, just like a general aspect. Thus, this subject is both known and unknown because although there have been a lot of attempts at trying to explain what is good and what is bad it is still an aspect that is being looked at different by different people.

"The moral philosopher seems to be theorizing about something with which she has little engagement (as suggested by the sharp contrast between the inner and the outer spaces), perhaps because she is scared of, or baffled by the object of her attention, or rather because this very condition is somewhat imposed on her by dynamics internal to the intellectual game she is supposedly playing, and whose validity she might be starting to 
question." At some point in our own lives we start to question pretty much everything that we do. It is something normal and it is to be expected because as the day goes on or as the action goes on we start to rethink what we said or what we did and we start to question if it was right or if maybe, after all, we should have gone in a different direction. Being moral does not mean that we do everything the right way and on the first try. It could actually mean that we are able to realize what we did and how it can affect others and more than that, moving one step further, it can be the defying aspect which guides us through this journey called life.

"[...] philosophical ethics should drop its foundational pretences and rather acquire an exhortative tone - that is, it should help us deal with the difficulties of the moral life often caused by our own attitudes toward our ordinary practices and their reflective counterparts and desiderata." 2 In theory this might sound like it is not a difficult task to achieve but the real life may see things from a different point of view. Everything that we do or that we do not do is going through a filter somewhere in our minds but also somewhere in our hearts. Even though at a first glance we might think a situation is not as bad as it seems, at a deeper search and at a more profound level of thinking and looking a something we might just realize that what we though at the previous level was not just wrong but was morally unacceptable.

"Broadly understood, intuitional ethics would include some right reason theories, some types of deontology, moral sensism, and psychological approbative types of ethics. [...] we will simply understand intuitionism as the -ethics that concentrates on the subjective attitude of the moral agent, rather than on the results of his action, in discussing what is morally good or bad." "On a different note, even though it might take some time for a human being to reach a final conclusion regarding the moral aspect of a particular situation or the moral aspect of one or more of his particular actions, we can say that we always experience the presence of something that we cannot explain. And that is the intuition, or what I like to call the right hand of morality. I say that because intuition is something that we all have, just like the moral aspect, it is something that we can sense and something that we can learn hoe to control, just like the other aspect, but at the same time it is also something that requires time in order to perfect.

Having this ability can lead us to better results in life simply because it might be easier for us to understand what we did wrong, how we got there, what is the philosophy behind it and what can we do to improve us as people in the future. Also, it might lead us to a better understanding of why others behave a certain way or why they judge us simply by our actions. "We make certain judgments of approbation or disapprobation of the conduct of other persons and these other-directed views and feelings are fundamental to ethics. When we attempt to judge our own conduct we reverse the process, as it were, and try to see ourselves as others see us.",

For a human being this might be the most difficult aspect of this life. It is not easy to look at yourself in the mirror and realize just who you really are and how exactly you got to that place. Now, understanding how someone else looks at you is a completely different aspect located on a completely different level. It is a very hard time and a very hard journey. But it is the moral thing to do. And it will also bring a lot of joy in the end as it helps us grow

\footnotetext{
1 Sarin Marchetti, Ethics and Philosophical Critique in William James, London, Palgrave Macmilla, 2015 , p.4

${ }^{2}$ Ibidem, p.18

${ }^{3}$ Vernon J. Bourke, History of Ethics, New York, Image Books, 1970, p.12

${ }^{4}$ Ibidem, p.18
} 
as persons in general. On a more particular aspect, it is also the right thing to do because it will lead us to a better understanding of someone else and it will help us when we are faced with criticism because we will be able to understand where someone is coming from and more importantly how they got to that place, what is their life philosophy and maybe even confront our moral believes with their own. And I say confront not because of the violent part but because of the fact that it will imply a profound discussion about what is wrong and what is right, about what they understand by having a moral attitude and by doing good in life and just putting everything out on the line.

"To say that the supreme principle of morality is binding on us (human agents) is to imply that we have an obligation to act in accordance with it. We ought to but, as a result of privileging inclinations over duty, might not follow its dictates. The same could also be said for any nonhuman rational agents who had characteristics, for example, natural cravings, on the basis of which they might act contrary to the supreme principle. The supreme principle's being binding on these agents would imply that they had an obligation to act in accordance with it."

It is not easy to live a moral live. It is even harder to try and teach others how to do the same and how to accept that what they might see and perceive as being moral might not be the same for the people that are putting it out there. A moral aspect is both a subjective and an objective one and it is up to us to resolve a situation, to put everything into place and sort things out. We are all humans after all and we make mistakes but if we have an open mind and if we are willing to discus what is happening we can agree on different solutions to improve ourselves. Morality is hard to understand and harder to apply. But it is not impossible. If we make a joint effort and put our minds to it. And most importantly, if we believe in what we do we can move mountains.

\section{THE GOOD AND THE BAD}

"[...] regarding Kant's basic concept to fit the supreme principle of morality. First, as we will see, there is more to Kant's concept of the supreme principle of morality than is captured in this basic concept. There are more features that, in Kant's view, the supreme principle would have to possess. It would, for example, have to be such that a proponent of its being the supreme principle of morality could coherently claim that obeying it "from duty" would have moral worth. ",

Just doing things because it is the right thing to do it may sound like it is something moral but as far as I am concerned it clearly isn't. Just because someone tells you to do something does not mean that you should. Juts because someone is doing something does not mean that you should. I believe that there is good moral but also bad moral. And these are some aspects that are crucial in life because we need to be able to distinguish between the both of them in order to make the right call. And after all it is what separates the good from the bad not just as far as actions are concerned but also as far as people and different behaviors are involved.

Also, "Kant makes it clear that, according to him, commonsense morality is committed to the view that absolute necessity and wide universal validity must be features of the supreme principle of morality. "7 It is something that I believe as well because like I said

\footnotetext{
${ }^{5}$ Samuel J. Kerstein, Kant's Search for the Supreme Principle of Morality, United Kingdom, Cambridge University Press, 2002, p.2

${ }^{6}$ Ibidem, p.3

${ }^{7}$ Ibidem
} 
before, we need to be able to distinguish between what is good and what is bad. On a higher level this might lead to more important aspects such as health, religion, education and even life in general. It is also thought that there is something more profound to this level of understanding something that requires years of hard work and dedication in order to be achieved. We might think that everything that we do is both good and moral but in the end it may come back to us on a different way than it was expected. And only then may see and learn that we were wrong and that the greater good decided that what we did was nowhere near it. "When a system is malfunctioning-when a young man becomes a drug addict and desperately steals jewelry from his grandmother or, when on a whim, someone carjacks an innocent stranger-one might explain this behavior by looking at the failure of the subsystems of knowledge, purpose, and affect. An attitude devoid of moral reflection indicates a damaged knowledge system. Apathy is symptomatic of a deadened sense of purpose, and a network of enterprise in such a case would be anemic and have no meaningful organization at all. ",

The bad in good is just like life as we know it in general. We need bad in order to compare it to something else and realize that it is bad and see what good looks life or what it feels like. Despite our actions, we might not be able to realize right away that we do not belong to the good moral part. Even harder than that it would be for us to realize that we are heading towards the bad and the negative spectrum. Yes, it is easy to say that we need to find and keep the right balance between good and bad while maintaining ourselves in the moral cluster of this day to day life. The hard part comes when we see the truth, when we feel on our own skin what we did to others and when we understand what life and what morality are really about. It is a very difficult task but I can say out loud that it is worth it. "In fact the very existence of morality (a fact which Kant takes as given) presupposes a rational and autonomous dimension to the self. For if our decisions were always merely mechanically determined, then it would make no sense-in the way that morality demands-for us to hold people responsible for their actions, and to assign praise and blame accordingly. On these terms, the supersensible self must be presumed to be both rational and free.",

First and foremost, we cannot hold someone responsible for what they did if we do not understand why they did it. And we can only understand that if we are able to explain it to someone else. And this is the general logic behind life and behind everything. It would be quite an act of racism I might say to hold someone responsible for their actions just by simply knowing that they did it. Yes, it is extremely difficult to want to understand others but if we cannot do it than we cannot except others to just do it for us. To be both good and moral, to understand morality and to let it rule your life and lead you to a better place and make you a better person is a full-time journey but it is filled with rewards and the destination is just simply amazing.

\section{CONCLUSION}

What I was looking for with this paper was to show that there is a common way towards morality, that there is both good and bad in life and that we are all people, we are all human beings. What that means is the fact that we all live and breath on this planet, we al have a say in what is going on, we all carry a weight on our shoulders and we will all be

\footnotetext{
${ }^{8}$ Doris B. Wallace, Education, Arts, And Morality. Creative Journeys, New York, Kluwer Academic, 2005, p.87

${ }^{9}$ Paul Crowther, The Kantian Sublime, Oxford, Clarendon Press, 1989, pp.17-18
} 
judge based on our actions, on our thought, on our ways of perceiving this world. We need to try and improve ourselves, we need to try and understand why someone is doing something that might seem wrong at a first glance but is just fine once we understand it. Philosophy, in general, helps us identify patterns that are linked to this life, helps us realize that they were there this whole time and even more that that it can also help us realize that we can use them to our own advantage.

Like I said it is a difficult task, it is a very difficult road but it is worth it. Because at the end of the way, without something good, without something moral what is there left? We might we all alone but if can live like that then we have reached a higher level of understanding and also a higher level of appreciating life. We know so many thing about it, we know maybe a few definition that we use when we are talking about morality but we really need to feel it on our own skin in order for us to be able to fully comprehend it.

This journey called life is not just amazing but is something that we thrive for and something that we really desire. We need to keep it, to improve it and to mage both good and morality a general aspect that defines it.

\section{BIBLIOGRAPHY:}

[1] Wallace B. Doris, Education, Arts, And Morality. Creative Journeys, New York, Kluwer Academic, 2005

[2] Kerstein J. Samuel, Kant's Search for the Supreme Principle of Morality, United Kingdom, Cambridge University Press, 2002

[3] Bourke J. Vernon, History of Ethics, New York, Image Books, 1970

[4] Crowther Paul, The Kantian Sublime, Oxford, Clarendon Press, 1989

[5] Marchetti Sarin, Ethics and Philosophical Critique in William James, London, Palgrave Macmilla, 2015 